\title{
DỨBin
}

Technological University Dublin ARROW@TU Dublin

2008-01-01

\section{Models, Modules and Abelian Groups}

\author{
Brendan Goldsmith \\ Dublin Institute of Technology, rendan.goldsmith@dit.ie \\ Ruediger Goebel \\ Universiaet Duisburg-Essen, R.Goebel@uni-due.de
}

Follow this and additional works at: https://arrow.tudublin.ie/corner

Part of the Mathematics Commons

\section{Recommended Citation \\ Goldsmith, B., \& Goebel, R. (2008). Models, Modules and Abelian Groups; In Memory of A.L.S. Corner. doi:10.1515/9783110203035}

This Book is brought to you for free and open access by the School of Mathematics at ARROW@TU Dublin. It has been accepted for inclusion in Corner Special Collection by an authorized administrator of ARROW@TU Dublin.

For more information, please contact arrow.admin@tudublin.ie, aisling.coyne@tudublin.ie, gerard.connolly@tudublin.ie.

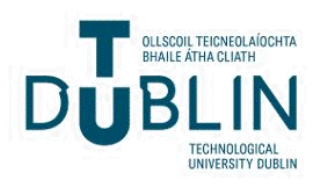




\section{School of Mathematics Articles}

\section{Models, Modules and Abelian Groups \\ Brendan Goldsmith* $\quad$ Ruediger Goebel ${ }^{\dagger}$}




\section{— Use Licence}

\section{Attribution-NonCommercial-ShareAlike 1.0}

You are free:

- to copy, distribute, display, and perform the work

- to make derivative works

Under the following conditions:

- Attribution.

You must give the original author credit.

- Non-Commercial.

You may not use this work for commercial purposes.

- Share Alike.

If you alter, transform, or build upon this work, you may distribute the resulting work only under a license identical to this one.

For any reuse or distribution, you must make clear to others the license terms of this work. Any of these conditions can be waived if you get permission from the author.

Your fair use and other rights are in no way affected by the above.

This work is licensed under the Creative Commons Attribution-NonCommercialShareAlike License. To view a copy of this license, visit:

- URL (human-readable summary):

http://creativecommons.org/licenses/by-nc-sa/1.0/

- URL (legal code):

http://creativecommons.org/worldwide/uk/translated-license 


\section{INTRODUCTION}

On hearing of the sudden death of A. L. S. Corner on September $3^{\text {rd }} 2006$, many of his friends and colleagues felt it appropriate that Tony's contributions to algebra should be acknowledged in a volume which would reflect his wide mathematical influence. Accordingly, this volume was conceived and its title "Models, Modules and Abelian Groups" reflects Tony's range of research interests. For many Tony's name is inseparable from "Abelian Groups" but his contributions were wider: his techniques from set and model theory, his interests in representation theory and non-commutative group theory and his enormous influence on the study of endomorphism rings are all part of his legacy and this is well reflected in the contributions herein.

Some short time prior to his death, the editors persuaded Tony that his unpublished work on the classification of the finite groups which can occur as automorphism groups of torsion-free Abelian groups, should be written up for publication. Tony agreed and his lecture notes on the topic, delivered at the University of Padua in 1988, were being processed when he died. He did not see the final version which is produced in this Volume, but we believe it is a faithful record of Tony's work on the subject. We are thankful to Federico Menegazzo for his help in this and particularly for his intriguing Appendix to Tony's paper.

The editors would like to record their thanks to the authors who responded so enthusiastically to their requests for contributions and to the referees who have ensured such high mathematical standards in the accepted papers. It is also appropriate to thank Robert Plato and Simon Albroscheit of Walter de Gruyter for their support and help in this undertaking.

Rüdiger Göbel and Brendan Goldsmith, Editors. 